\title{
Jogi képviselet szerepe az alapvető jogokat sértő fogvatartási körülmények miatt indított kártalanítási eljárásban
}

\author{
The Importance of Legal Representation \\ in Compensation Procedure Initiated \\ for Fundamental Rights-violating Placement Conditions
}

\begin{abstract}
Absztrakt
A büntetés-végrehajtás során kifejtett jogi képviselethez kötődő jogok és kötelezettségek nem koherensek más összefüggő jogszabályi rendelkezéssel, ebből adódóan a különböző illetőségü büntetés-végrehajtási intézetek (továbbiakban: bv. intézetek) és a büntetés-végrehajtási bíróságok (továbbiakban: bv. bíróságok) előtt eltérően értelmezik, alkalmazzák ezen rendelkezéseket, és ez a disszonancia megjelenik a kártalanítási eljárásokban is. Ez a differencia érzékelhető a fogvatartott által indított a szabadságvesztése során elszenvedett a börtönzsúfoltságból eredő alapvető jogokat sértő elhelyezési körülményekből eredő sérelmei kompenzálása iránti kártalanítási eljárásban, amely egy olyan új jogintézmény, amely büntetőeljárási, büntetés-végrehajtási és polgári eljárás elemekkel vegyes. Ez az új jogintézmény ún. preventív eszközként került bevezetésre a büntetés-végrehajtási törvényünkben, amely a zsúfolt elhelyezési körülmények miatti, speciális jogcímen alapul. Jelen tanulmányom középpontjában a túlzsúfoltságból eredő alapvető jogokat sértő elhelyezési körülmények miatt indított kártalanítási eljárást röviden bemutatom be röviden, hogy is épült be a magyar jogrendszerünkben, valamint a kártalanításos eljárásban kifejtett jogi képviseletét vizsgálom, összehasonlítva a büntetések, az intézkedések, egyes kényszerintézkedések és a szabálysértési elzárás végrehajtásáról szóló 2013. évi CCXL. törvény (továbbiakban: Bv. Kódex) és a büntetőeljárásról szóló 2017. évi XC. törvény (továbbiakban: új Be.) rendelkezései keresztmetszetében. Jelen tanulmányomban rá szeretnék világítani azokra az eltérésekre, amelyek a kártalanításos eljárást oly mértékben érinthetik, hogy az akadályba ütközhet és fennakadhat. Értekezésem célja továbbá, hogy olyan javaslatokat tegyek, amelyek segíthetik az új Be és Bv. Kódex jogi képviseletre vonatkozó
\end{abstract}


szabályozásainak egységessé válását a bv. intézetek előtt, és a bv. bírói eljárásokban. A kártalanítási eljárásban kifejtett jogi képviseletet eddig más szakirodalom ilyen mélységben nem vizsgálta, így jelen publikációm kifejezetten a kártalanítási eljárás jogi képviseletének jelenlegi magyar szabályozásra, értelmezésre és alkalmazásra szorítkozik, közvetetten hivatkozom azon szakirodalmakra, amelyek megállapításaimat alátámaszthatják.

Kulcsszavak: büntetés-végrehajtás, kártalanítási eljárás, jogi képviselet, büntetőeljárás, védő, fogvatartott

\section{Abstract}

The rights and obligations associated with legal representation in prison are inconsistent with other related legal provisions, and therefore differently interpreted and applied by pre-trial penitentiary institutions (hereinafter referred to as criminal institutes) and penitentiary courts (judiciary courts). This dissonance appears in the indemnification proceedings as well. This difference can be perceived in the compensation procedure for compensating for the injuries resulting from placement conditions that violate the fundamental rights of prisoners who have been deprived of their liberty during imprisonment: this is a new legal body with mixed elements of criminal procedure, penitentiary and civil proceedings. This new legal institution has been introduced as a preventive tool in our Prison Act, which is based on a special title due to crowded housing conditions. In this study, I focus briefly on the compensation procedure initiated for placement conditions that violate fundamental rights resulting from overcrowding, how it incorporated our legal representation in the Hungarian compensation system in comparison with the enforcement of sanctions, measures, certain coercive measures and the closure of offenses. CCXL 2013 (hereinafter: the Code of Civil Procedure) and Act XC of 2017 on Criminal Procedure. (hereinafter: the New Act). In this study I would like to highlight the differences that may affect the compensation procedure to such an extent those can affect clash and stall. The dissertation also aims to make suggestions that can help the new Be and Bv. Code of Conduct on Legal Representation for Unification of the bv. institutes and bv. judicial proceedings. So far, other legal literature has not generatred scrutiny about legal representation in the compensation procedure, so my present publication directly refers to the current Hungarian regulation, interpretation and application of the legal representation of the indemnification procedure, indirectly I refer to the literature that can support my findings. 
Keywords: penitentiary, indemnification, legal representation, criminal prosecution, defender, prisoner

\section{A kártalanítási eljárás, mint preventív eszköz}

A magyarországi börtönök körülbelül 120 százalékos telítettséggel müködnek. A fogvatartotti populáció átlagos létszáma a 2010 és 2014 közötti időszakban folyamatosan növekvő tendenciát mutatott, mely az elmúlt években némileg megtorpanni látszik. A 2015. évben az éves záró adatok alapján az átlaglétszám csökkent, majd a 2016. évben enyhén emelkedett. A 2017-es évben az éves átlaglétszám ismét csökkenést mutat. Jelenleg az ország 35 büntetés-végrehajtási intézetében közel 18000 fogvatartott raboskodik, a börtönviszonyokkal kapcsolatos problémák a magyar társadalom igen széles rétegét érintik. (Börtönstatisztikai Szemle 2018/1, 4.)

Az Emberi Jogok Európai Egyezményben is érvényesülnek a mindenkit megillető jogok és szabadságjogok. A fogvatartás körülményeit érintő 3. cikk deklarálja, hogy senkit sem lehet kínzásnak, vagy bánásmódnak, vagy büntetésnek alávetni. Az egyezmény végrehajtása érdekében létrehozta az Emberi Jogok Európai Bíróságot (European Court of Human Right rövidítve: ECoHR, továbbiakban: EJEB). A EJEB-nek nagy és kiemelkedő szerepe van abban, hogy az embertelen bánásmód vagy büntetés tartalmát esetjogi döntéseivel megtöltötte. A különféle fogvatartási körülményeket érintő ügyekben hozott ítéletek útmutatóként szolgálnak. A testület megállapította, hogy a büntetés-végrehajtási hatóságok a panaszosok számára 3,3 négyzetméternél kevesebb személyes mozgásteret biztosítottak, továbbá a túlzsúfoltsághoz nem megfelelő fogvatartási körülmények társultak (pl. a szegényes higiéniai környezet (a WC nem megfelelő leválasztása), a megfelelő szellőztetés hiánya stb.) Az EJEB a Varga és társai kontra Magyarország ügyben 2015. március 10-én meghozott, ún. vezető ítéletében (Varga and Others v. Hungary, nos. 14097/12, 45135/12, 73712/12, 34001/13, 44055/13, 64586/13) (HARASZTI 2008/3, 56.) arra kötelezte Magyarországot, hogy tegyen intézkedéseket a büntetés-végrehajtási intézetek túlzsúfoltságának csökkentésére. Az EJEB ítéletében megállapította, hogy a fogvatartottak rendelkezésére álló mozgástér és egyéb nem megfelelő körülményekkel együtt olyan mértékủ szenvedést okozott a panaszosoknak, amely meghaladta a fogvatartással szükségszerüen együtt járó szenvedés mértékét.

Ahhoz, hogy Magyarország a fenti EJEB pilot-ítéletekben foglalt kötelezettségeinek eleget tegyen, az Országgyülés 2016. október 25-én elfogadta a büntetés-végrehajtási intézetekben fennálló zsúfolt elhelyezési körülmények miatti 
kártalanításról szóló 2016. évi CX. törvényt, amelyben bevezette az alapvető jogokat sértő elhelyezési körülmények miatt benyújtható panasz és az ilyen elhelyezési körülményekből eredő sérelem orvoslására szolgáló kártalanítási eljárást, mint preventív eszközként szolgáló, speciális jogcímen alapuló sui generis intézményt. Egyúttal kérte, hogy az EJEB az új jogszabályt vizsgálja meg, hogy az hatékony és kimerítendő jogorvoslatoknak számít a fogvatartási körülményeket vizsgáló ügyekben.

A Bíróság ezzel a kérdéssel a Domján-ügyben (Domján v. Hungary, no. 5433/17, 14 November 2017.) foglalkozott. Az 2016. évi CX. törvény kétféle jogorvoslati lehetőséget vezetett be: egy megelőző és egy kompenzációs jellegüt. A büntetések, az intézkedések, egyes kényszerintézkedések és a bv. szabálysértési elzárás végrehajtásáról szóló 2013. évi CCXL. törvény (a továbbiakban: Bv. Kódex.) új 144/B. §-a lehetőséget teremtett arra, hogy az elítélt és a védő az alapvető jogokat sértő elhelyezési körülmények miatt panasszal éljen a büntetés-végrehajtási intézet parancsnokánál, aki megalapozott panasz esetén megteszi a szükséges intézkedéseket a körülmények javítása érdekében, ha pedig a jogszabályban elöírt élettér az adott intézetben nem biztosítható, kezdeményezi a fogvatartott más - megfelelö körülményeket biztosító - intézetbe való átszállítását. Ha és amennyiben az alapvető jogokat sértő elhelyezési körülmény megszüntetése sem az adott büntetés-végrehajtási intézeten belül, sem más intézetbe való átszállítással nem oldható meg, az intézet parancsnoka intézkedik a sérelem ellensúlyozása érdekében. A parancsnok határozata ellen a büntetés-végrehajtási bíróhoz intézett halasztó hatályú felülvizsgálati kérelemmel élhet mind az elítélt, mint a védője.

A kompenzációs jellegü jogorvoslatot a Bv. Kódex. új 10/A. §-a teremti meg, amelynek értelmében kártalanítás jár az elítéltnek vagy az egyéb jogcímen fogvatartottnak a fogva tartása során a jogszabályban elöírt élettér biztosításának hiánya és az ehhez az esetlegesen kapcsolódó más, a kínzás, kegyetlen, embertelen vagy megalázó bánásmód tilalmába ütköző elhelyezési körülmény, különösen az illemhely elkülönítésének a hiánya, a nem megfelelő szellőztetés, világítás, fütés vagy rovarirtás (a továbbiakban együtt: alapvető jogokat sértő elhelyezési körülmények) által előidézett sérelem miatt. A kártalanítás minden egyes, az alapvető jogokat sértő elhelyezési körülmények között eltöltött nap után jár, egy napra eső összege legalább 1200, de legfeljebb 1600 forint. A kártalanítás megfizetésére az állam köteles.

A kártalanítási igény benyújtásának föszabály szerint két formai feltétele van: egyrészt az elhelyezési körülményekkel kapcsolatos fent említett panaszeljárás előzetes igénybevétele, másrészt pedig a hat hónapos benyújtási határidő megtartása. (Azokra vonatkozóan, akiknek a fogva tartása már koráb- 
ban megszűnt, vagy már a Bv. Kódex. módosítása előtt panasszal fordultak a Bírósághoz, a törvény tartalmaz bizonyos átmeneti rendelkezéseket is.) (Mohácsi 2017/6. 193-195.)

Mindezekre való tekintettel az Emberi Jogok Európai Bírósága 2016. november 23-án megállapította, hogy szükséges egy olyan új hazai jogorvoslati rendszer kialakítása, amely alkalmas lehet a panaszosok sérelmeinek orvoslására, egyúttal ez alapján az összes ilyen tárgyú kérelem vizsgálatát felfüggesztette.

Az elítélt és az egyéb jogcímen fogvatartott elhelyezésére szolgáló, jogszabályban meghatározott zárka minimális mértékét, és a kártalanítási eljárás részletszabályait a Bv. Kódexen túl a szabadságvesztés, az elzárás, az előzetes letartóztatás és a rendbírság helyébe lépő elzárás végrehajtásának részletes szabályairól szóló 16/2014. (XII. 19.) IM rendelet (továbbiakban: IM rendelet) határozza meg. Ezen jogszabályt azonban a jogalkotói szintén módosította a 24/2016. (XII. 23.) IM rendelet 28. §-ával, 2017. január 01.-ei hatállyal. 2017. január 01. napjától a zárkában vagy a lakóhelyiségben elhelyezhető létszámot úgy kell meghatározni, hogy minden elítéltre hat köbméter légtér és egyéni elhelyezés esetén legalább 6, közösen elhelyezett elítéltek esetén személyenként legalább 4 négyzetméter élettér jusson. Az élettér kiszámításakor a zárka vagy a lakóhelyiség alapterületéből az illemhely és a mosdó által elfoglalt területet - függetlenül attól, hogy ezek leválasztása megtörtént-e - figyelmen kívül kell hagyni. Egyéni elhelyezés esetén a zárka vagy lakóhelyiség alapterületének el kell érnie a 6 négyzetmétert. Ugyanakkor a mozgástér meghatározása szempontjából a zárka, vagy a lakóhelyiség alapterületéből az azt csökkentő berendezési és felszerelési tárgyak által elfoglalt területet figyelmen kívül kell hagyni. A kártalanítási igény iránti formanyomtatványon fel kell tüntetni pontosan, hogy melyik büntetés-végrehajtási intézetben, milyen időszakokban nem volt biztosítva a jogszabályban elöírt élettér, továbbá, hogy ehhez esetlegesen kapcsolódó milyen más, a kínzás, kegyetlen, embertelen vagy megalázó bánásmód tilalmába ütköző elhelyezési körülmény állt fenn. A szabályozásból egyértelmüen következik, hogy a kártalanítást minden esetben a kínzás, kegyetlen, embertelen vagy megalázó bánásmód tilalmába ütköző zsúfolt elhelyezési körülmény alapozza meg. A büntetés-végrehajtási bíró a sérelem mértékének megállapításakor veszi figyelembe a zsúfolt elhelyezésből eredő sérelmet súlyosító körülmények fennállását, halmozódását. Jelenleg rendkívül eltérő a bírói gyakorlat azzal kapcsolatban, hogy az elhelyezési körülmények súlyosságát mi alapján értékelik. Szerencsés esetben a bíró a sérelmek súlyosságának mérlegelésekor tekintettel van arra is, hogy a biztosított élettér mennyivel volt kisebb, mint a jogszabályban elöírt és ennek megfelelően határozza meg a napi kártalanítási összeget. Ugyanakkor a jogalkotó nem zárta el az elítélteket attól a lehetőségtől, hogy az ezen túl elszenvedett bármiféle 
joghátrányt, sérelmeiket, valamint az ezzel kapcsolatos kártalanítási igényüket egyéb törvényes úton (pl.: polgári perben) érvényesítsék. (Bv. Kódex 10/B. §)

Így jelenleg az EJEB-hez már csak a hazai jogorvoslati lehetőség kimerítése után lehet fordulni, abban az esetben, ha a hazai kártalanítás olyan okból nem vezetett eredményre, ami az Emberi Jogok Európai Egyezményében védett jog megsértésével kapcsolatos. Tehát például önmagában azzal, hogy a magyar bíróság alacsonyabb összegú kártalanítást ítélt meg, mint amit korábban - a hazai jogorvoslat hiányában - az EJEB megítélt, nem lehet az EJEB-hez fordulni.

Rendkívül nehéz az alapvető jogokat sértő körülmények okozta sérelmek bizonyítása a fogvatartott részéről. Gyakori probléma, hogy míg az elítélt kártalanítási kérelmében ugyan leírja, hogy zárkájában poloskás volt a matrac, a büntetés-végrehajtási intézet a kártalanítási kérelemmel kapcsolatban előterjesztett véleményében közli, hogy „az elöírásoknak megfelelően végezték a rovarirtást" és így a bíróság a fogvatartotti panaszt bizonyíték hiányában nem találja megalapozottnak. Álláspontom szerint a fogvatartottal szemben ez az eljárás méltánytalan. Hiszen a Bv. Kódex $1 . \S(1)$ bekezdése rögzíti a következő alapelvet: „A büntetés-végrehajtás feladata a büntetési célok érvényesitése a büntetés, illetve az intézkedés végrehajtásán keresztül, azzal a célkitüzéssel, hogy a végrehajtás során, az egyéniesités szempontjait biztositani kell annak érdekében, hogy az megfelelöen szolgálja az egyéni megelözési célok elérését." Az egyéniesítés, és a társadalomba való visszailleszkedés elősegítése nem csak az oktatás, munkáltatás, vagy egyéb aktív programon történő részvétellel valósítható meg, hanem mindazoknak a határozatoknak, végzéseknek tükrözniük kell az egyéni elbírálást, amelyek a zárkaadatokat, zárkakimutatásokat és bv. intézetek nyilatkozatait tartalmazzák.

A kártalanítási eljárás során hozott végzés ellen a kézbesítéstől számított 8 nap áll a rendelkezésre fellebbezni, és a végzés ellen nem csak a kérelmezö, de az ügyész is fellebbezhet, kérheti a kártalanítási összeg csökkentését, de felemelését is. (Bv. Kódex 10/B. §)

A kártalanítás kifizetésére jogerős döntés az Igazságügyi Minisztériumnak történő kézbesítésétől számított hatvan napon belül (általában hatvan nap elteltével) kerül sor. A jogszabály ugyanis lehetôvé teszi, hogy a megítélt kártalanításból levonásra kerüljön az a polgári jogi igény, kártérítés vagy sérelemdíj, amit a vonatkozó időszak alatt végrehajtott szabadságelvonásokat kiszabó itéletekben ítéltek meg, illetve a gyermektartásdij behajtása iránti végrehajtási eljárásban követelt összeg.

A kártalanítási eljárás nem a leggyorsabb eljárás, akár egy-két évig is eltarthat. A bíróságok előtt több ezer kérelem van elbírálás alatt, kevés létszámmal dolgozzák fel, és a büntetés-végrehajtási intézetek lassan szedik össze a fog- 
vatartás körülményeire vonatkozó adatokat és minél hosszabb volt a fogvatartási időszak, minél több büntetés-végrehajtási intézetet érint, annál lassabb lehet a kérelem elbírálása.

\section{A védelemhez való jog hazai alapjai}

A büntető felelősségre vonás folyamata során az emberi jogoknak, alapelveknek, a nemzetközi elvárásoknak, követelményeknek érvényesülniük kell, ami a jogállamiság egyik alapvető fokméröje Európában. (Vókó 2010.) A 2013. október 22-i 2013/48/EU európai parlamenti és tanácsi irányelv (Vókó György: Bünelkövetők jogkorlátozása jogállamban, MTA Értekezés 2010.) (továbbiakban: irányelv) a fogvatartottak alapvető jogairól, a büntetőeljárás során és az európai elfogatóparancshoz kapcsolódó eljárásokban ügyvédi segítség igénybevételéhez való jogról, valamint valamely harmadik félnek a szabadságelvonáskor történő tájékoztatásához való jogról és a szabadságelvonás ideje alatt harmadik felekkel és a konzuli hatóságokkal való kommunikációhoz való jogról rendelkezik. Az irányelv rendeltetése, hogy a tagállamok számára minimumszabályokat határozzon meg a terhelteknek a büntetőeljárás során az ügyvédi segítség igénybevételéhez, a harmadik személy értesítéséhez, valamint a harmadik személyekkel és a konzuli hatóságokkal történő kommunikációhoz való jogáról. Az irányelv kimondja, hogy a terhelt szabadságának elvonása esetén a tagállamoknak meg kell tenniük a szükséges intézkedéseket, hogy ezen személy ténylegesen gyakorolni tudja az ügyvédhez való jogát, kivéve ha erről a jogáról lemondott. (2013/48/EU európai parlamenti és tanácsi irányelv 28. pontja) Biztosítani kell, hogy a jogi képviselő az illetékes hatóságoknál érdeklődhessen a szabadságelvonással érintett személy fogva tartásának körülményeiröl. (2013/48/EU európai parlamenti és tanácsi irányelv 29. pontja)

„A büntetöeljárási szabályok akkor vannak összhangban az alkotmánnyal, ha a terheltnek biztositják a védekezéshez törvényesen igénybe vehetö eszközöket, az eszközök szabad megválasztásának jogát. A terheltet ebben még védöje, adott esetben hivatalból kirendelt védöje sem korlátozhatja." (FARKAS 1993) A védelemhez való jog alaptörvényi szintủ szabályozása értelmezésre és kiegészítésre szorul: mindenekelött azt kell leszögezni, hogy elsősorban ez a jog valóban több mint a védekezéshez való jog. Magában foglalja a professzionális védöügyvédhez való jogot. Másodsorban a büntetőeljárás teljes menetére kiterjed, beleértve a büntetés-végrehajtási szakaszt is. Nemcsak a terheltté nyilvánított személyt, hanem bármely eljárás alá vontat (tehát a feljelentettet, az elítéltet is) megilleti. 
A büntetés-végrehajtást szerteágazó garanciarendszer övezi. A Bv. Kódex tehát mindezekre figyelemmel alapelvi szinten garantálja a büntetés-végrehajtási ügyben a védelemhez való jogosultságot. A Bv. Kódex eléggé szüken határozza meg a védői jogokat. A törvény a védőnek - nyilvánvalóan az ügy megismerése érdekében - irat-betekintési jogot biztosít, az ügy előbbre vitelének elösegítése céljából pedig garantálja a nyilatkozattételi jogot.

Egyrészt a Bv. Kódexben és az új Be.-ben is bv. bíróságokra vonatkozó feladatkörök találhatók meg, amelyekre vonatkozóan a jogalkotó egységbe foglaltan részletszabályokat határozott meg a fogva tartott személy esetében a büntetőeljárás lefolytatása, továbbá a büntetőügyekben hozott határozatok végrehajtása során a bíróságokra és egyéb szervekre háruló feladatokról szóló 9/2018. (VI. 11.) IM rendeletben. A 9/2018. (VI. 11.) IM rendelet külön a 64. pontjában határozza meg a kártalanítási eljárásban bv. bíróság további betöltendő feladatát. Álláspontom szerint a védői jogai és kötelezettségei, valamint meghatározott feladatai közé sem lehet falat állítani, hanem azokat kiterjesztően kell értelmezni, és alkalmazni, mint a bv. bíróságok esetében.

\section{A védő definiálása és jogosítványainak meghatározása}

Bv. Kódex 11. § (1) szerint „Az elítéltet és az egyéb címen fogvatartottat a büntetés-végrehajtási ügyben megilleti a védelem joga, a védönek iratmegismerési és önálló nyilatkozattételi jogosultsága van."

A Bv. Kódex és a Be. szorosan összefügg egymással, azonban a védő fogalmát és jogosítványait, mint ahogy arra az előző fejezetben utaltam, eltérően határozza meg. A Be. a védőt nem pontosítja, csupán annyit határoz meg, hogy meghatalmazás vagy kirendelés alapján ügyvéd járhat el védőként.(Be. 41. § (1) A Be. külön alfejezetben emeli ki a védő jogait és kötelezettségeit, és leszögezi, hogy a terhelt mindazon jogát gyakorolhatja önállóan vagy védői jogként, amely nem csak a terhelt személyéhez füződik. Továbbá a védő az eljárási cselekményekben való jelenlétet is szabályozza. (Bv.tv. 9. pont)

Megemlítendő, hogy 247/B/1998. AB határozat vezette be azt, hogy az elítélt által személyesen és külön engedély nélkül, illetőleg a védője útján párhuzamosan is gyakorolható az „általános körü kérelmezési és panaszjog, valamint jogorvoslati jog, amelyek együttesen hivatottak biztosítani, ,, hogy az elitélt a büntetés-végrehajtás folyamatában ne váljék kiszolgáltatottá és a legszélesebb körben érvényesüljön a végrehajtás egésze feletti birósági, illetve ügyészségi kontroll. ” Bv. Kódex a védőt hivatalos kapcsolattartónak minősíti, másrészt a védőt a Be. szerinti védőként jelöli meg, valamint a büntetések és az intézke- 
dések végrehajtása alatt az elítélt vagy az egyéb jogcímen fogvatartott büntetés-végrehajtási ügyében eljáró ügyvédet is védöi pozícióba helyezi.(Bv. Kódex 15. pont) A Bv. Kódex a kártalanítási eljárásban védőnek nevezi azt, aki az elítélt vagy az egyéb jogcímen fogvatartott érdekében eljár, és jogi képviselőnek azt, aki a szabadult elítéltet vagy egyéb jogcímen fogvatartottat képviseli. (Bv. Kódex 10/A. § (5) bekezdés) Azonban a különböző fogalmak összefüggéseit az azokhoz füződő eljárási jogosítványokat sem részletezi a Bv. Kódex. Csak a védenc érdekében eljáró védő önállóságát, jogosítványát határozza meg szükre szabottan, miszerint iratmegismerési és önálló nyilatkozattételi joga van. ( Bv. Kódex 11. § (1) bekezdés) Maga a Javaslat is egy értelmező rendelkezést iktat be. A Bv. tv. 3. § 15. pontja értelmében ugyanis a büntetést kitöltve szabaduló elítélt, illetve a szabadított egyéb jogcímen fogvatartott esetében védőről már nem beszélhetünk, de az elítélt és az egyéb jogcímen fogvatartott jogosult az alapvető jogokat sértő elhelyezési körülmények miatt indított kártalanítási eljárásban jogi képviselőt meghatalmazni. A jogi képviselő jogosítványai ezen eljárásban az értelmező rendelkezésből következően a védő jogosítványaival azonosak lesznek.

Az ügyvéd, a védő, a jogi képviselet fogalmakat az ügyvédi tevékenységről szóló 2017. évi LXXVIII. törvény (továbbiakban Ütv.) rendezi. Az Ütv. 40. § (2) rendelkezése szerint az ügyvéd a védői tevékenysége ellátása során, a terhelt védekezéshez való joga gyakorlásának keretei között, a terhelt érdekeinek elsődlegessége alapján jár el. A jogi képviselet pedig egy gyüjtőfogalom, ebbe beletartozik az ügyvédi, a jogtanácsosi, európai közösségi jogászi képviselet. (Ütv. 39. § (1) bekezdés)

Látható, hogy a Bv. Kódexben megjelenik a jogi képviselet, a védő és az ügyvéd fogalmak, de eltérő helyeken, szinte egymástól függetlenül használja. Azt az érzést kelti ez a szerkezeti megoldás, mintha az ügyvéd, a jogi képviselő és a védő különböző eljáró személyek lennének, akiknek eltérő jogosítványaik vannak. Mégis a legkirívóbb differencia a védői kör és eljárása. A Bv. Kódex utal az új Be. szerinti védőre, így álláspontom szerint a Be. szerinti védői jogoknak és kötelezettségeknek szintúgy érvényesülnie kellene a bv. intézetek előtt és a kártalanítási eljárásban.

A Kúria Joggyakorlat-elemző Csoportja előtt (Kúria Büntető Kollégium Jogygyakorlat-elemző csoport 2017. EL. II. H. 13. büntetés-végrehajtás) is a védő a Be. szerinti védö, valamint a büntetések és az intézkedések végrehajtása alatt az elítélt vagy az egyéb jogcímen fogvatartott bv. ügyében eljáró ügyvéd. (Bv. tv. 3. § 15. pont) Az alapvető jogokat sértő elhelyezési körülmények miatti kártalanítás iránt indított büntetés-végrehajtási bírói eljárásokban védő alatt a jogi képviselőt is érteni kell. (Bv.tv. 50. § (7) bekezdés) Így a kártalanítási el- 
járásban, amikor a bv. bíró bekéri a börtön elhelyezésről szóló adatszolgáltatásokat a bv. intézetektől, akkor azokat az iratokat a védő részére is át kell adni, hogy jognyilatkozatot, észrevételeket tudjon tenni. Mivel kifejezetten a törvény nem tartalmaz ilyen rendelkezést, így a védő csak a bírói végzésből szürheti le a bv. intézetek nyilatkozatait.

Ezek alapján az a következtetés szürhető le, hogy a kártalanítási eljárásban, is mint védö jár el és nem csak iratmegismerési és önálló nyilatkozattételi joga van, hanem mindazok a jogosítványok is megilletik, amelyek a Be. deklarál. Amennyiben a kártalanítási eljárás során ügyfél meghallgatásra kerülne sor, a bv. intézetnek a védői képviseletet biztosítani. Amennyiben erre nem kerül sor álláspontom szerint ebben az esetben az ügyféltől származó nyilatkozat jogi szempontból nem értékelhető.

\section{Védenc és a védő kapcsolattartása}

A védenc és a védő kapcsolattartása sokszor ütközik falakba, amely szintúgy a gyakorlatban érezhető a leginkább. A Bv. Kódex 11. § (6) bekezdése szerint a fogvatartott képviselöjével ellenőrzés nélkül „érintkezhet”. A Be. ezzel ellentétben a terhelttel kapcsolatban ellenőrzés nélküli tanácskozást ír. (Be. 39. $\S$ (1) bekezdés) Véleményem szerint az érintkezés többletet hordoz magában. Az érintkezés kifejezi a védő és a védence között a tanácskozáson túl, az iratok közös megismerését, áttanulmányozását, aláírását. A kártalanítási eljárás során is, tekintve, hogy törvényi módosításokra került sor (Ütv, Be, Bv. Kódex) és a kártalanítással kapcsolatos bírói felhívásoknak is meg kell felelni, elengedhetetlen az iratok közösen történő elemzése, esetleges módosítása, vagy a védenc személyes, írásos nyilatkozatának beszerzése. A bv. intézetek többsége strukturálisan olyan védői beszélőket alakított ki, amely akadályozza az ügyvédi/védői titok alá eső iratok átadását. A védő arra van kényszerítve, hogy a védői/ügyvédi titok alá eső iratokat átadja a börtönőrnek, aki kézbesítőként továbbadja a védencnek. Véleményem szerint mivel megismerhetővé válhatnak az iratok, a fenti helyzet sérti a védenc és a védő közötti kapcsolatot, a védő megsértheti az ügyvédi/védői titoktartási kötelezettségét. Egyes esetekben nincs arra lehetőség, hogy közvetlenül a fogvatartott részére ügyvédi/védői iratok átadásra kerüljön, vagy bizalmasabban tanácskozzanak a védői beszélők leszigetelése miatt.

A másik sérülékeny pontja a védő és a védence közötti kapcsolatnak a későbbi kapcsolatfelvétel nehézsége. Az elítélt és a védője által benyújtott panasz beadása után, a parancsnok a panasz elbírálásakor határozatával dönt an- 
nak megalapozottságáról vagy megalapozatlanságáról. (IM rendelet 10/A. § (1) bekezdés) Megalapozottság esetén a parancsnok bv. intézeten belül enyhít a fogvatartás körülményein (általánosságban elmondható, hogy több sétaidőt ajánl fel az elítéltnek), vagy ha kevésbé zsúfolt másik bv. intézetbe történő átszállításról dönt, akkor a fogvatartott a kapcsolattartási jogának a sérelme nélkül átszállítható. Nincsen olyan jogszabályi kötelezettsége a bv. intézetnek, hogy a védőt értesítse védence átszállításáról. A védő adatszolgáltatás kérésekor, vagy iratbeadáskor szembesül védence más tartózkodási helyéről. A kártalanítási eljárás hiánypótlásait, nyilatkozattételi felhívásait 8, illetve 15 napra korlátozza a bv. bíró, amely miatt a panasz és a kártalanítási igény akár érvényét is veszítheti, ha a panaszos vagy védője nem teljesíti időben. (IM rendelet $10 / \mathrm{C} \S(2)$ bekezdés)

\section{Zárógondolatok}

A kártalanítási eljárásban meglátásom szerint a jogi képviselet inkább védői pozíciót tölt be a Bv. Kódex és a Be. szerinti védői jogosítványokkal van felruházva a bv. bírói eljárásban, és a bv. intézetek előtt. Szükségesnek vélem a Bv. Kódex anyagi jogi szabályozásának átgondolását atekintetben, hogy a jogi képviselet fogalma egyértelmüvé váljon minden eljárásban szereplőnek, és ezen felül föképpen a Be. szerinti védői jogosítványok beépítését a Bv Kódex szerinti eljárásokba. Az átszállításokkal kapcsolatban elengedhetetlennek érzem a védő értesítését - akár elektronikus rendszeren keresztül - a védence átszállításáról. Hiszen a védő és védence kapcsolata nem csorbulhat a védenc átszállítás miatt sem. Végezetül olyan ügyvédi/védői beszélgetők kialakítása szükséges, amely egyszerübbé teszi a kapcsolattartást, az iratok átadását, azok közös elemzését a védő és a védence között. Végül véleményem az, hogy szükséges a kártalanítási eljárás kiegészíteni olyan rendelkezésekkel, amelyek a védői eljárást megkönnyítik, miszerint a védő mindazokat az iratokat megkapja, amelyek az eljárás során keletkeznek akár bv. intézeti akár ügyészi oldalról, amelyekre észrevételeit megteheti a bv. bíróság előtt. A jogszabályi hiányok és a rossz gyakorlatokból fakadó eltéró értelmezés és alkalmazása miatt nem egyformán érvényesül a különböző bv. intézetek előtt és bv. eljárásokban a védői képviselet, így a védelem hatékonysága és a védői jogosítványok gyakorlása csorbul és akadályoztatva van. Álláspontom szerint a Bv Kódexen - nem csak ebben a körben - is szükséges egy teljes megújítás, annak érdekében, hogy annak alkalmazása és értelmezése az új Be.-vel együtt sokkal könnyebbé és simulékonyabbá váljon az eljárás szereplöinek számára. 


\section{Felhasznált irodalom}

Bérces, V. (2012): A védői szerepkör értelmezésének kérdései - különös tekintettel a büntetőbíróság elötti eljárásokra. Kézirat.

Farkas, Á. - Pap, G. (1993): Alkotmányosság és büntetöeljárás. Kriminológiai és Kriminalisztikai Évkönyv, Budapest

Haraszti, M. K. (2008): A kinzás és az embertelen vagy megalázó bánásmód és büntetések tilalma az ENSZ és az Európa Tanács legfontosabb dokumentumaiban, valamint az állampolgári jogok országgyülési biztosának tevékenységében. Acta Humana, 3.

Mohácsi, M. (2017): Alapjogi jogesetek - a strasbourgi Emberi Jogok Európai Bírósága. Acta Humana, 6.

Vókó, Gy. (2010): Bünelkövetők jogkorlátozása jogállamban. MTA Értekezés

\section{Felhasznált jogszabályok}

Varga and Others v. Hungary, nos. 14097/12, 45135/12, 73712/12, 34001/13, 44055/13, 64586/13 Domján v. Hungary, no. 5433/17, 14 November 2017.

Az Európai Parlament és a Tanács 2013/48/EU irányelve (2013. október 22.) a büntetőeljárás során és az európai elfogatóparancshoz kapcsolódó eljárásokban ügyvédi segítség igénybevételéhez való jogról, valamint valamely harmadik félnek a szabadságelvonáskor történő tájékoztatásához való jogról és a szabadságelvonás ideje alatt harmadik felekkel és a konzuli hatóságokkal való kommunikációhoz való jogról

247/B/1998. AB határozat

A büntetések, az intézkedések, egyes kényszerintézkedések és a szabálysértési elzárás végrehajtásáról szóló 2013. évi CCXL. törvény

A büntetőeljárásról szóló 2017. évi XC. törvény

Az ügyvédi tevékenységről szóló 2017. évi LXXVIII. törvény

A szabadságvesztés, az elzárás, az előzetes letartóztatás és a rendbírság helyébe lépő elzárás végrehajtásának részletes szabályairól szóló 16/2014. (XII. 19.) IM rendelet

A fogva tartott személy esetében a büntetőeljárás lefolytatása, továbbá a büntetőügyekben hozott határozatok végrehajtása során a bíróságokra és egyéb szervekre háruló feladatokról szóló 9/2018. (VI. 11.) IM rendeletben

T/21179. számú törvényjavaslat indokolással - A Büntetések, az intézkedések, egyes kényszerintézkedések és a szabálysértési elzárás végrehajtásáról szóló 2013. évi CCXL. törvény és ehhez kapcsolódóan más törvények módosításáról

Kúria Büntető Kollégium Joggyakorlat-elemző csoport 2017. EL. II. H. 13. Büntetés-végrehajtás 